\title{
Chapter 6 \\ Schools of Democracy? Giving Circles and the Civic and Political Participation of Collaborative Philanthropists
}

\author{
Angela M. Eikenberry
}

The New River Valley Change Network, a group of about 12 individuals with varying backgrounds and experiences, meets once a month in members' homes and offices in Blacksburg, Virginia, to give away money they contribute to a fund held at the local community foundation. Each member donates about $\$ 10$ a month or $\$ 100$ a year. Members decide together, through a consensus decision-making process, where to give their money. The group occasionally invites community experts and activists to their meetings to learn about projects or organizations in need of funding. They prefer to fund small organizations and endeavors that might lead to social change.

Washington Womenade holds volunteer-organized potluck dinners where attendees donate $\$ 35$ to a fund that provides financial assistance to individuals who need help paying for prescriptions, utility bills, rent, and so on. "Members" show up when they choose, and the focus of time together is highly social. In 2002, a Real Simple magazine story on Washington Womenade led to the creation of dozens of unaffiliated Womenade groups across the country. This article also inspired Marsha Wallace to launch Dining for Women, now a US-based national network of more than 400 chapters across the country in which women meet for dinner monthly and pool funds they would have spent eating out, to support internationally based grassroots programs helping women around the world.

BeyondMe is an expanding network of small teams made up of young professionals. Members of each team select a charity or social enterprise to support for one year after reviewing brief proposals, often requiring a "Dragon's Den" or "Shark's Tank" pitch by the charity or social enterprise as part of the selection process. Members, on average, donate $£ 4,000$ and 150 volunteer hours to the chosen

\footnotetext{
A. M. Eikenberry $(\square)$

School of Public Administration, University of Nebraska Omaha, Omaha, NE, USA

e-mail: aeikenberry@unomaha.ed
} 
organization. Teams support a variety of causes, including jobless young offenders, homeless youth, and women who have experienced abuse and sexual exploitation. BeyondMe's staff and most teams are based in London, UK.

The groups described above — called giving circles — are examples of a growing movement emerging across the US, the UK, and elsewhere. They are philanthropic voluntary associations ${ }^{1}$ that involve individuals pooling resources to support organizations and individuals of mutual interest. They also include social, educational, and engagement opportunities for volunteer members, connecting participants to charities, communities, and one another. Although giving circles come in a range of sizes and foci, these groups' key and defining attributes are that they involve individuals who together decide on support for organizations (and sometimes individuals) through giving money (and sometimes time). They also informally or formally educate members about philanthropy, charities, and issues in the community; include a social dimension; engage members in grant making and running the group; and typically maintain independence from any one charity or social enterprise (Eikenberry, 2007, 2009). Hundreds of giving circles have been identified across the US, and a growing number have formed in the UK and elsewhere (Bearman, 2007a, 2007b; Bearman, Carboni, Eikenberry, \& Franklin, 2017; Eikenberry, 2009; Eikenberry \& Bearman, 2009; Eikenberry \& Breeze, 2015; John, Tan, \& Ito, 2013; Rockefeller Philanthropy Advisors, 2009; Rutnik \& Bearman, 2005).

Giving circles are much like the voluntary groups-where individuals voluntarily come together to accomplish a purpose-that have been a staple of the American and British landscape for some time; one can see similarities in Women's Clubs and Kiwanis, Rotary, or book club or church groups. However, what makes giving circles different is their express philanthropic purpose (i.e., they are created to give money or other resources to organizations or causes), the environment in

\footnotetext{
${ }^{1}$ Philanthropy's meaning and manifestations have changed a good deal throughout history, as Merle Curti (1968/1973) articulates. Scholars today have come to broadly define it as the act of giving money and other resources, including time, to aid individuals, causes, and organizations. Payton and Moody (2008) define it as "voluntary action for the public good." Philanthropy is a term distinct from nonprofit and tax-exempt organizations, charities, and voluntary associations, though all are interrelated. Voluntary associations predate (as those described by Alexis de Tocqueville (1835/2000) in Democracy in America), continue to exist alongside, or sometimes become nonprofit and charitable organizations. They are made up of individuals who voluntarily come together to accomplish a purpose and range from informal self-help or study groups to more formal organized groups such as the Kiwanis or League of Women Voters. A main characteristic of a voluntary association is that it is run by volunteers (Driskell \& Wise, 2017). Nonprofit organizations are those organizations designated in the United States by a state as a nonprofit corporation and often by the US Internal Revenue Service as tax-exempt. The term nonprofit, then, is used to designate a legal and regulatory status for an organization that typically does work related to the arts, education, health care, and social welfare. Nonprofit organizations can be quite diverse, ranging from small, human service organizations, such as homeless shelters or arts centers, to large, federated organizations, such as the American Red Cross or Salvation Army, to substantially endowed universities, hospitals, and foundations. Charity is a legal term used in the UK to define organizations established for charitable purposes only and is subject to the control of the High Court's charity law jurisdiction.
} 
which they have emerged and in which they operate, and their typically informal and independent structures. Giving circles represent a transformation in the way less affluent people are attempting to address community problems through giving and volunteering manifested in the "new philanthropy" environment. They demystify the philanthropic process and enable individuals to do something charitable, in their own way (Eikenberry, 2009). This is a response to and reflection of larger changes taking place in a society that is increasingly individualized and where traditional federated associations are losing their grassroots natures (Hustinx, 2010; Lorentzen \& Hustinx, 2007; Painter \& Paxton, 2014).

As the authors of the literature below describe, much has been written or speculated about traditional voluntary associations as "schools of democracy," teaching people civic skills and virtues and serving as avenues for civic and political participation. Many scholars have questioned and tested the validity of these claims and the degree of cause and effect between voluntary association membership and civic and political participation, generally finding positive relationships, but with some variations by level and length of participation and type of association. Debate continues about the degree to which voluntary associations cause greater civic and political engagement or attract people already prone to such engagement. However, the authors of existing research mainly focus on traditional associations and large-scale data sets that make it difficult to unpack the "conditions needed to encourage people... to develop civic virtues and skills and get involved in politics" (Dekker, 2014, p. 56); they also tend to put little focus on philanthropy, which is inherently a political act but not often acknowledged as such (Nickel \& Eikenberry, 2013). This is important because policy actors have increasingly looked to philanthropy and nongovernmental institutions to address community problems, including supporting areas of basic needs and education (Giridharadas, 2018; Henriksen, Smith, \& Zimmer, 2012; Pharoah, 2011).

Studying giving circles enables addressing some of these issues by asking the question: Does participation in these new forms of philanthropic voluntary association lead members to increase their civic and political participation? That is, do giving circles serve as schools of democracy by providing educational or other features that lead participants to become more civically or politically engaged? Indicators of civic participation include: giving, volunteering, and participation in efforts to address community problems. Indicators of political participation include participation in efforts to change government policy and participation in other political activities such as voting and contacting public officials (Keeter, Zukin, Andolina, \& Jenkins, 2002; van der Meer \& van Ingen, 2009). To examine the research question, I draw on data gathered in the US and the UK through surveys of current and past members of various types of giving circles and control groups of donors not in giving circles, as well as semi-structured interviews with giving circle members. I focused my data collection on the US and the UK because they have the longest established and largest number of giving circles globally. Although the two countries' philanthropic cultures differ in important ways, as described below, both have promoted philanthropy and voluntary association as policy alternatives to public social welfare and as a response to public sector austerity. 
The rest of the chapter is organized as follows: First, I provide an overview of the relevant literature pertaining to the research focus, starting with a discussion of voluntary associations and their relationship to civic and political participation as schools of democracy, moving on to the changing social and philanthropic environment, and finally discussing giving circles. Second, I outline an overview of my methodology. Thirdly, I present my findings. I finish the paper with discussion and conclusions.

\section{Voluntary Associations, the Changing Environment and Giving Circles}

Voluntary associations have long been viewed as important mechanisms for promoting democracy, an idea often attributed to Alexis de Tocqueville's (1835/2000) observations during his tour of America in the early 19th century. Tocqueville believed that through engagement in voluntary associations, citizens learned civic virtues and skills, participated directly in governance, and improved the quality and equality of representation in governance-they served as schools of democracy (Fung, 2003; Lichterman, 2006). Building on Tocqueville's observations, scholars see voluntary associations as a means for citizens to achieve the virtues necessary for democratic citizenship: trust, moderation, compromise, reciprocity, and skills of democratic discussion and organization (Newton, 1997; Warren, 2001). Almond and Verba (1963/1989), in their comparative analysis of political culture in five countries, showed that voluntary association membership had a positive impact on civic and political competence. Putnam (1993, 2000) also suggested members of voluntary associations display more political sophistication, social trust, and civic and political participation than others. Further, Verba, Schlozman, and Brady (1995) found voluntary associations of all types provide opportunities for "the acquisition of politically relevant resources and the enhancement of a sense of psychological engagement with politics" (p. 4). They note that even when individuals pursue activities with no direct political content, such as chairing a committee to arrange a fundraising event, they have opportunities to develop organizational and communication skills that are relevant for politics and learn to tolerate and to deal with diverging opinions. McLeod et al. (1996) contend voluntary associations can provide exposure to political cues, social contact, and recruitment networks that facilitate civic and political participation; Musick and Wilson (2008) write that engagement in voluntary associations can make people more aware of what is happening in their community and the structural nature of social problems and the need for political solutions.

Many have questioned and tested the validity of these claims and the degree of cause and effect between voluntary association membership and civic and political participation in numerous countries and contexts (e.g., Dekker, 2014; Dekker \& van den Broek, 1998; Howard \& Gilbert, 2008; Jeong, 2013; Newton \& Montero, 2007; 
Parry, Moyser, \& Day, 1992; Schulz \& Bailer, 2012; van der Meer \& van Ingen, 2009; van Deth, 1997), generally finding positive relationships with some exceptions and variations by level and length of participation and type of association. In particular, scholars disagree on the importance of "intensity" of participation and connection to civic and political participation. Putnam $(1993,2000)$ highlighted the importance of active (face-to-face) versus passive (check-writing) involvement in associations' impact on social capital and participation. Others have found intensity to have little or no significant effect (Almond \& Verba, 1989; van der Meer \& van Ingen, 2009; Verba, Schlozman, \& Brady, 1995; Wollebæk \& Selle, 2003). However, Wollebæk and Selle (2003) found in relation to social capital a cumulative effect of participation when the member belongs to several associations simultaneously.

There is also debate about the socialization effect of voluntary associationsthat associations make citizens civically and politically active-versus a selection effect - that certain personality traits stimulate citizens to join voluntary associations and engage in political activities at the same time, without a causal relation between the two (Armingeon, 2007). Through their study of 17 European countries, van der Meer and van Ingen (2009) found the additional effects of "active" participation were marginal and the correlation between associational involvement and political action was not explained by the accumulation of civic skills and civic mindedness through the association. They concluded that "voluntary associations are not the schools of democracy they are proclaimed to be, but rather pools of democracy" (p. 281); that is, "voluntary associations do not make citizens politically active, but bring politically active citizens together" (p. 303). Dekker (2014) also surmised based on his analyses of more than a dozen countries' voluntary association participation data that for some people, involvement in voluntary associations and voluntary work are stepping stones towards politics, whereas for others it offers an opportunity of doing something for the community without getting involved in politics. In other words, participation in associations has different effects depending on the person. Thus, within the literature on the connection between voluntary associations and civic and political participation, there is need for more work to "unpack the conditions" that lead people to get involved in community affairs and politics (Dekker, 2014, p. 56). Researchers looking at the connections between voluntary association and civic and political participation have so far done little to account for societal shifts and changes in participation in traditional social structures.

Scholars suggest that societies are in the midst of a social transformation from "collectivistic" to "individualistic" and "institutionalized" to "self-organized" (Hustinx \& Lammertyn, 2003, p. 168). Social relations have changed from being close to loose, permanent to provisional, and thorough to superficial (Gundelach \& Torpe, 1996, p. 12). Beck describes society as increasingly characterized by the dissolution of traditional parameters and "variation and differentiation of lifestyles and forms of life, opposing the thinking behind the traditional categories of large-group societies..." (as cited in Ellison, 1997, pp. 711-712). In this context, traditional "voluntary associations have become optional" (Gundelach \& Torpe, 1996, p. 13) 
and indeed, active membership in such associations, at least in the US, appears to be in decline (Painter \& Paxton, 2014; Putnam, 2000; Skocpol, 2002).

Scholars have documented the growing use of informal, self-organized, and decentralized initiatives. The emergence of small, self-help support groups and peer-to-peer sharing (e.g., Archibald, 2007; Borkman, Karlsson, Munn-Giddings, \& Smith, 2005; Wuthnow, 1994) as well as "network associations"-looser, more informal, and personal forms of association (Fung, 2003; Gundelach \& Torpe, 1996; Wuthnow, 1998) — are, according to Wuthnow (1994), rooted in both a breakdown of traditional support structures_-neighborhoods and family_and a continuing desire for community; they have "emerged as a serious effort to combat forces of fragmentation and anonymity in our society" (p. 40). Within these types of small and informal associations, engagement is often directed toward concrete problem solving in everyday life. Individuals want (or have) to cope with day-to-day problems on their own terms and in their own way; unlike previous generations, they are uninterested in engagement that is full-time and life-long (Bang \& Sørensen, 1999; Macduff, 2005; van der Pennen \& Schreuders, 2014). Wuthnow (1998) writes that "instead of cultivating lifelong ties with their neighbors, or joining organizations that reward faithful long-term service, people come together around specific needs and to work on projects that have definite objectives" (p. 8).

Giving circles are indicative of this trend in shifting organizational structures and desire for more hands-on engagement. Studies of the landscape of giving circles in the US and the UK (Eikenberry, 2009; Eikenberry \& Breeze, 2015) show that many are formed of small groups and networks, and that participants view giving through the giving circle as a much more proactive approach to philanthropy than has traditionally been the case. One of the most often cited reasons people say they join giving circles is the chance to become more engaged in the giving process- to be doing more than just writing a check and also interacting directly with nonprofit organizations. Some also say they appreciate the simple, nonbureaucratic nature of the giving circle-it's fun, and a chance to be social "while doing good" (Eikenberry, 2007).

But what do these new forms of association mean for engaging individuals in civic and political areas? Based on interviews and document analysis, Eikenberry (2009) found giving circles generally provide opportunities for democratic participation within the group - they provide opportunities for agenda setting, decision making and face-to-face deliberative discourse - and they also build members' capacities through education about voluntary organizations, community issues, and philanthropy. Many groups in the US emphasize formal donor education (Bearman, 2007b; Eikenberry, 2009; Moody, 2008). Do giving circles—as new and emerging forms of philanthropic voluntary associations - increase civic and political participation for members? In the next section, I describe the methodology I use to address this question. 


\section{Methodology}

In this section, I provide an overview of the methodology I used to address the research question. I gathered data primarily through surveys of giving circle members and control groups of people not in giving circles, supplemented by interviews with giving circle members in the US and UK. I describe these methods in more detail below.

I focused my data collection on the US and UK because these countries have the longest established and largest number of giving circles globally and because both countries have in recent years promoted philanthropy and voluntary association as policy alternatives to public social welfare and as a response to public sector austerity. However, the UK has a very different philanthropic culture than the US-where the US has long touted itself as the most philanthropic of nations and philanthropy enjoys historical popularity, in the UK, as Wright (2001) notes, "while it has enjoyed a very recent renewal of interest . . . for many in Britain it still carries disparaging connotations of Victorian 'do-gooderism' and is often seen as elitist, patronizing, morally judgmental, and ineffective, as well as old-fashioned and out-of-date. . . It is perceived as an idea whose time came, was proved unworkable, and went - to be replaced by a universal, fair, and more efficient welfare-state" (p. 400). This has been changing in recent years as there have been a number of efforts to promote charitable giving and strengthen the culture of philanthropy in the UK (Pharoah, 2011; The Philanthropy Review, 2011; Sargeant \& Breeze, 2004; Walker, 2014), with the emergence of giving circles due in part to these efforts.

Eikenberry and Breeze (2015) outline similarities and differences between giving circles in the US and UK. Structurally, both countries have similar types of groups, including some that are focused on specific demographic groups such as young professionals. The UK also has some types of giving circles, such as the live crowd-funding model, that are unique to it. In both countries, giving circles are typically initiated by someone who heard about or had the idea themselves; they are seen as an alternative to "mainstream" philanthropy, partially focus on developing philanthropy, and many emphasize networking/socializing. In the UK, there is additional focus on "normalizing" giving in a context that lacks widespread cultural affirmation for philanthropy. There is also a larger focus on the pursuit of solidarity and social change. In both countries, giving circles mainly give money (and time) and feature various decision-making processes and types of events. Those in the UK generally appear to place less emphasis on grant-making due diligence and instead rely on trust in fellow members and beneficiaries. UK groups also appear more staff driven and put less emphasis on formal educational programming. Although members in both countries come from a mixture of backgrounds, the total percentage of race/ethnicity, women, or other identity-based groups is lower in the UK. 


\section{Surveys}

My colleagues and I administered surveys of giving circle members and control groups of people not in giving circles in the US and the UK. We originally administered a survey in the US to understand if and how participation in a giving circle has changed members' behavior related to giving, volunteering, and civic and political engagement. In addition, we asked if and how participation in a giving circle changed members' awareness or knowledge about philanthropy, nonprofit organizations, and community issues. Finally, we wanted to know if and how participation in a giving circle changed members' perceptions or attitudes about philanthropy, community issues, government and nonprofit roles and responsibilities, and political and social values. With our UK survey, we updated and revised the US version to address some cultural differences as well as to improve its usefulness for the giving circles that participated in the survey, while also trying to maintain questions that could be used for comparison across countries. In presenting the data reported below, I focus on the findings related to civic and political behaviors. ${ }^{2}$

We constructed and administered the US survey via paper and internet between November 2007 and April 2008. The sample included 26 giving circles, drawn from the Forum of Regional Association of Grantmakers' giving circle database, consisting of giving circles that represented various types and sizes and identity groups (e.g., women, African-American, young professionals) in order to get a broad cross-section of data. The giving circles in the sample also represented a range in terms of years of existence and geographic locations. In choosing this sample, we also took into consideration earlier studies that had been published on particular giving circles. We recruited giving circle members and past members through giving circle leadership in each giving circle in the sample. The control group included a random sample of donors to a University Foundation supplemented with a nonrandom sample of public administration graduate students and alumni.

We administered the UK survey online between April 2014 and February 2015. Seven giving circles or networks of circles participated in the study, including those representing a diversity of types of giving circles in the UK, with an oversampling of young philanthropist groups. It was fairly reflective of the broader landscape of giving circles in the UK, as young philanthropist groups account for the largest number of circles and participants. The control group was made up of a UK university's donors and of people who said they were just starting with a giving circle (had been members for less than one month).

For the US, we sent surveys to approximately 890 giving circle members and 938 individuals in the control group - a total of 1,828 people. We estimated the overall response rate at $37 \%$. The response rate was $48 \%$ for giving circle members and $23 \%$ for the control group. Giving circle respondents in the US sample were

\footnotetext{
${ }^{2}$ See a copy of the US survey here: https://www.academia.edu/12175637/The_Impact_of_Giving Together_Full_Report. For a copy of the UK survey, go to: https://drive.google.com/ file/d/0B0D7zXPukqEQbHliY2EzNkRjNjQ/view?usp=sharing.
} 
significantly more likely to be female, from diverse racial/ethnic groups, and older on average than the control group. In addition, giving circle members attended religious services significantly less frequently than the control group. Regarding political orientation, giving circle members were more significantly likely to describe themselves as liberal or middle-of-the-road compared to the control group. Finally, there was a large difference between giving circle members and the control group in the amount they say their households donated to charity over the past year. The mean for giving circle members was $\$ 7,682$ compared to $\$ 4,945$ for the control group. This difference was statistically significant. However, the average annual family income of giving circle members was also significantly higher than the control group: around $\$ 106,500$ compared to around $\$ 90,000$. There was no significant difference between giving circle members and the control group for educational level, years living in current community, marital status, and number of children.

For the UK survey, we emailed about 4,184 people the survey link (through contacts at each giving circle or network) and 507 people answered part or all of the survey - an overall response rate of $12.1 \%$. Ultimately, there were 359 useable responses-201 giving group respondents and 158 control group respondents. The demographic characteristics of the UK giving circle and control group respondents were largely similar except for a few areas: Giving circle respondents were significantly more likely to be 30 to 39 years old, say they found it "difficult to get by on present income," and to be married. They were significantly less likely to be male, from an Asian ethnicity, retired, living in the Southeast of England, living in their community less than one year, and single. There were no significant differences for mean age, ranges in income, education, or religious attendance. The UK survey did not include a question about political orientation.

Dependent variables included in the survey to measure civic and political participation featured the following (drawing on Keeter et al., 2002; van der Meer \& van Ingen, 2009):

- Giving: measured by asking all respondents for their best estimate of the total amount they contributed during the past 12 months (US) or month (UK). Giving circle members were also asked about the degree to which their giving had changed due to the giving circle.

- Volunteering: measured by asking all respondents for their best estimate of the total number of hours they had volunteered during the past month (asked in the UK only). Giving circle members in the US and UK were also asked about the degree to which the amount of time they volunteer changed due to the giving circle.

- Efforts to address problems in the community: measured by asking giving circle members in both countries about the degree to which their participation in efforts to address problems in the community changed due to the giving circle.

- Efforts to change government policy: measured by asking giving circle members in both countries about the degree to which their participation in efforts to change government policies at the local, national, or international levels changed due to the giving circle. 
- Participation in civic and political activities: measured by asking all respondents in both countries if they had participated in certain activities during the past year such as: working with others to solve a problem in the community; voting; talking to others about an election or campaign; signing a petition about a social or political issue; and other items noted in more detail below.

The above dependent variables were examined in relation to four independent variables:

- Participation in a giving circle: measured by asking all respondents if they belonged to a giving circle or giving group, defined in the US survey as "a group of individuals who pool money and other resources and decide together where to give these away. This does not include donor recognition programs that nonprofit organizations use to honor donors." It was defined in the UK survey as: "A giving group involves individuals collectively donating money and/or time to support charitable organizations, projects or individuals. Participants in the group typically have input on how funding or other support is spent and often participate in discussions and social and educational events about philanthropy and the charitable sector."

- Level of participation within a giving circle: measured by asking giving circle members about the degree to which they had participated in certain activities within a giving circle in the past 12 months (US) or had participated in as a member of the giving group (UK), such as taking part in deciding who received funding, going on site visits, volunteering with a funding recipient, doing research, or holding leadership position(s).

- Length of time participating in a giving circle: measured by asking giving circle members how long they had been a member of a giving circle (US) or had participated in the giving group (UK). If a respondent indicated being in more than one giving circle, they were asked to answer based on the giving circle they had participated in the longest.

- Participation in multiple giving circles: measured by asking giving circle members how many giving circles they currently belong to (US) or number of giving groups in which they had participated in the past five years (UK).

These four independent variables can provide some indication of the degree to which giving circles may serve as "schools" increasing civic and political participation. If giving circles serve as schools increasing civic and political participation, we would see not only that people in a giving circle would have higher participation than to those not in giving circles, but this participation would rise with more engagement (in one or more giving circles) and length of engagement.

To analyze the survey data, we calculated frequencies and percentages for all items and means when applicable. We created descriptive statistics based on all respondents, comparing giving group respondents to control group respondents, and comparing across giving groups. We then created crosstabs using SPSS Custom Tables for questions that contained at least one nominal response field. We performed T-tests to determine whether means were statistically significantly different 
between the giving circle and control group response, and calculated the Pearson Correlation to measure the strength of the relationship between level of engagement and dependent variables. We utilized the one-way analysis of variance (ANOVA) to determine whether there were any statistically significant differences between continuous numeric variables, as was the case with length of engagement and number of giving circles, and dependent variables.

\section{Interviews}

In the US, we conducted 30 interviews with a purposively selected sample of members from 11 giving circles. Giving circle leaders helped make contact with members. We interviewed giving circle members with varying levels of involvement in the group, length of membership, gender and gender orientation, profession, and racial/ethnic identity. They were also members of different types of giving circles. Interviews were conducted on the telephone, recorded, and transcribed. They took place between December 26th, 2007, and May 23rd, 2008, and ranged from 22 minutes to 55 minutes, with the average length 36 minutes.

In the UK, we conducted 26 interviews with a sample of members from 14 giving circles. We selected a sample of giving circles that included a range of characteristics based on size, structure, geographic location, and demographic make-up, and mostly engaged with the lead contact in the group; however, in some groups we talked to more than one member. There were three group interviews and in two giving groups geared to young professionals, we talked to multiple members individually (three in one group; six in another). Interviews took place between April 10 to September 9th, 2013, and February 24th to April 21st, 2015, across the UK.

We analyzed transcripts using MAX QDA qualitative data analysis software and followed an iterative process of contextualizing and categorizing strategies (Maxwell, 1998, p. 90). This process included: listening to the entire interview and reading transcripts and other documents completely through to get a sense of the whole, rereading and coding segments, and recoding and grouping codes into broad clusters of similar topics or nodes, primarily around the research questions though allowing for emergent topics. We then iteratively recoded these clusters into more specific and simplified codes, creating "trees" (Coffey \& Atkinson, 1996, p. 29).

\section{Findings}

I have drawn the findings described from data from surveys and interviews to examine the impact of giving circles on members' civic and political participation in relation to each of the dependent variables: giving, volunteering, participation in efforts to address problems in the community, participation in efforts to change 
government policy, and participation in other activities such as voting and contacting public officials. See a summary of the results in Table 6.1.

\section{Giving}

People in giving circles in the US donated more on an annual basis than people who were not in giving circles. The mean for giving circle members was $\$ 7,681$, compared to $\$ 4,944$ for the control group. This difference was statistically significant. However, because the average annual family income of giving circle members was also higher than the control group, there was no statistically significant difference for average household contributions between these two groups when controlling for income. Nonetheless, two-thirds $(67 \%)$ of giving circle members indicated the total amount they contributed each year had increased due to giving circle participation. Kahn (2007) and Moody (2008) had similar findings with their studies of Social

Table 6.1 Giving circle impact on civic and political participation-US \& UK

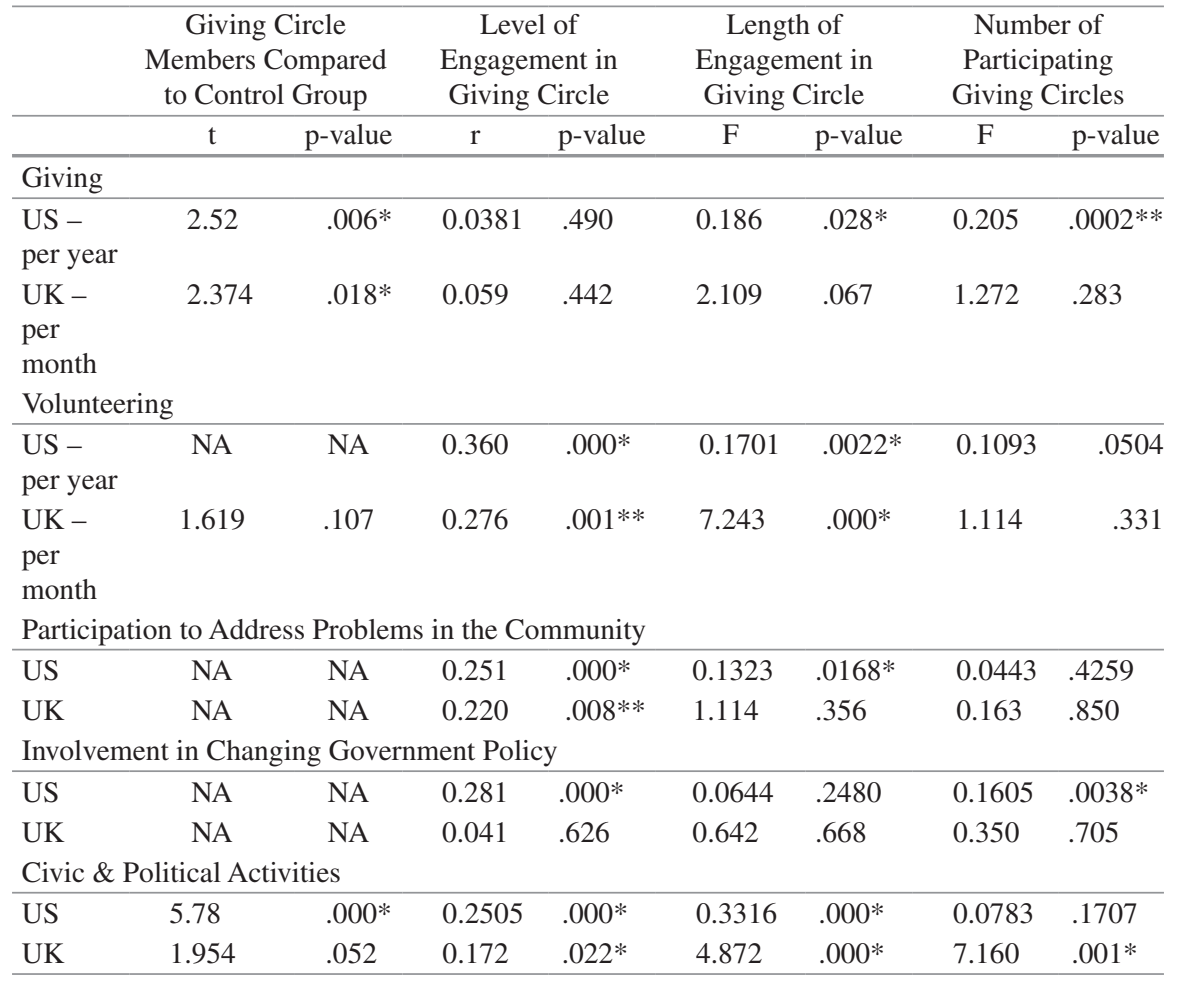

*Correlation is significant at the 0.05 level (2-tailed)

**Correlation is significant at the 0.01 level (2-tailed)

Note. Source: Design by author 
Venture Partners. This may mean, then, that giving circle members said giving increased when it did not, the increased amount was not big enough to make a statistically significant difference, or they gave less before and are now more like the control group. At least one-third of those interviewed in the US said their personal giving had increased since joining a giving circle. In addition, a handful of interviewees indicated their giving had shifted from elsewhere to the giving circle or had decreased due to retirement and job loss since joining the giving circle.

In the UK, giving circle respondents gave significantly more per month on average than the control group ( $£ 253$ vs. $£ 108$ per month), even when controlling for income. This difference, however, is largely due to giving by those with household incomes of $£ 75,001$ or above, where giving group respondents gave significantly more than control group respondents, on average $£ 353$ compared to $£ 103$ per month. Nonetheless, three-quarters $(77 \%)$ of giving circle participants said the giving group caused them to increase or substantially increase the amount they give each year. Similarly, reports on impact done by UK-based The Funding Network (TFN) in 2012 found that $66 \%$ of TFN members said they give more to charity as a result of their participation in TFN. A perceived increase or expansion in giving was also brought up frequently in interviews with members.

We further examined the effect of giving circle participation on members' giving by looking at association with level and length of engagement in the group, and number of groups in which members engaged. The findings for the US show levels of engagement within the giving circle were not significantly associated with total amount contributed. However, total contributions rose significantly as the length of time in the giving circle increased, even when accounting for income. In addition, people in more than one giving circle donated significantly more than other members, with an average of $\$ 13,400$ compared to $\$ 6,834$ for members in one giving circle and $\$ 4,945$ for people in no giving circles. The association between number of giving circle memberships and the total amount given was highly significant and remained so when controlling for income. This suggests, then, that given enough time or participation in several groups, giving circles influence members to give more. However, in the UK, the amount given per month was not significantly associated with level or length of engagement, nor number of giving groups in which a member participated.

\section{Volunteering}

In the US, a little less than half (46\%) of giving circle members reported that participation in a giving circle increased the amount of time they volunteered. In addition, at least half of interviewees said that when they joined a giving circle, they already had a long history of volunteering, dating back to high school and through pro bono neighborhood work, volunteering with the United Way, a church, or elsewhere. Thus, it may be that for some, there is an impact on increasing volunteering but for many they were already active before joining the group. Studies of SVP found that 
$63 \%$ to $68 \%$ of respondents noted an increase in their volunteerism after joining SVP (Kahn, 2007; Moody, 2008). This higher amount might be explained by the fact that SVP focuses much more on member volunteering than many other giving circles. It may also be that volunteering increases with engagement level and over time.

In the UK, although giving circle members did on average volunteer at a higher rate per month than the control group respondents ( 7.15 vs. 6.30 hours per month), there was no significant difference between giving circle members and the control group. In addition, only $43 \%$ of giving circle respondents said the giving group helped to increase or substantially increase the amount of time they volunteer each year. The impact report on TFN done in 2012 also found that 29\% of respondents said they volunteered more or had become a trustee to an organization they had met through TFN. A few members also said in interviews that they got involved volunteering with charities beyond their giving group.

The US and UK data show members were more likely to say their total time volunteering significantly increased as their level of engagement and length of participation in a giving circle increased. They also said their volunteer time increased as participation in the number of giving circles increased, but the association was not significant in either country. Thus, overall, although people may already come to the giving circle having been active as a volunteer, as they are more involved in the giving circle and for a longer period of time, they increase their rate of volunteering.

\section{Participation in Efforts to Address Problems in the Community}

Two-thirds (64\%) of US giving circle members said the giving circle led them to increase their participation in efforts to address problems in the community. In the UK, 53\% said the giving group caused them to increase or substantially increase their participation in efforts to address problems in the community, whereas $47 \%$ said participation had not changed in this area. As level of engagement and length of engagement increased, US giving circle respondents were significantly more likely to say they increased their participation in efforts to address problems in the community. This increased for the number of giving circles as well, but it was not significant. In the UK, giving circle respondents were significantly more likely to say they increased their participation in efforts to address problems in the community as their level of engagement in the giving circle increased. There was no significant association when it came to length of engagement or number of giving groups. It seems in this area, then, level of engagement in both countries, and length of engagement in the US, have some kind of effect on increasing members' participation in addressing problems in the community. 


\section{Involvement in Efforts to Change Government Policy}

Only one-third (34\%) of US giving circle respondents said they increased their involvement in changing government policy due to the giving circle; however, as both the level of engagement within the giving circle increased and the number of these circles increased, respondents were significantly more likely to say they increased their participation in efforts to address problems in the community. There was also a positive but not significant association between length of participation and involvement in changing government policy. In the UK, only $14 \%$ of giving group respondents said the giving group caused them to increase or substantially increase their involvement in changing government policies. There was no significant association when it came to level or length of engagement, nor number of giving groups. In this area, giving circles seem to have little effect in members' participation in changing government policy; in the US, however, these efforts do seem to increase with level of engagement in the giving circle and when participating in multiple giving circles.

\section{Civic and Political Activities}

In both surveys, we created an index to show the degree of overall civic and political engagement based on a number of activities in which people might participate (there were a total of 14 activities in the US survey and a total of 9 in the UK survey). ${ }^{3}$ The index average for US giving circle members was 8.8 compared with 7.3 for the control group. This difference was statistically significant. However, further analysis showed that only some income groups showed a statistically significant difference between giving circle and control group respondents: incomes of $\$ 25,000$ to $\$ 34,999$ and $\$ 50,000$ to $\$ 149,999$. SVPI also found in their survey of partners that

\footnotetext{
${ }^{3}$ Civic engagement indicators were created based on the index used by CIRCLE: Center for Information and Research on Civic Learning and Engagement: http://www.civicyouth.org/practitioners/Core_Indicators_Page.htm\#1. These include: working with others to solve a problem in the community; volunteering; belonging to a group or association; donating money; voting; talking to others about an election or campaign; contacting public officials; contacting a media outlet to express an opinion on a social or political issue; protesting, marching, or demonstrating; signing a petition about a social or political issue; and either buying or not buying something because of a company's social or political values. For the UK survey, we used a revised and trimmed down version that included: took part in a protest, march, or demonstration; contacted a newspaper or other media to express your opinion about a political or social issue; helped raise money for a charitable cause; contacted or visited a public or elected official to express your opinion; belonged to a voluntary group or association, either locally or nationally (such as a trade union, professional association, political or social group, sports or youth group); signed a petition about a political or social issue; voted in a local, national, or European election; worked together with someone or a group to discuss or address a problem in the community; bought or did not buy something because of the social or political values of the company that produces or provides it.
} 
$70 \%$ of respondents indicated SVP had some, significant, or a primary impact on their community involvement as well (Kahn, 2007). In the UK, the index average was 4.2 for giving circle members and 3.8 for the control group. The difference was not significant. The only significant difference was that a higher portion of giving group respondents indicated they had worked together with someone or a group to discuss or address a problem in the community.

Furthermore, in the US, as level of engagement in the giving circle increased, the civic and political engagement index significantly increased. It was also evident from the survey that length of time in a giving circle and number of giving groups were positively but insignificantly associated with the index of civic and political engagement. In the UK, civic and political activities were significantly higher as the level and length of engagement in the giving circle as well as the number of giving groups increased.

According to US interviews, the number of members who said they were more civically and politically active because of the giving circle was small. However, those who did think they had become more active due to the giving circle included those who had become motivated by a growing awareness of community problems through the giving circle and thus become more involved in local elections, writing elected officials, or supporting various groups and paying closer attention to social issues, and those who were inclined to be active but were not because they did not feel they had previously had a good avenue for such action. For example, since joining her giving circle, one respondent began identifying other ways to effect change, including joining the Committee for World Outreach. Another interviewee discussed how the giving circle meetings enabled her to learn about local issues and then take action. Three people talked about how their experience in a giving circle inspired them to talk more about political issues with their friends and family and helped them figure out where to go to get something done.

Even if civic and political activities did not increase, some indicated giving greater thought to the relationship between what they learned through the giving circle and their behaviors. For example, one interviewee said the giving circle made her question whether she was doing enough. Others saw the giving circle as another way to be active. Interviewees in the UK indicated that politics were not a focus of the group, although they could come up indirectly. One person in a mentor group noted:

In [giving group] everyone's very polite so you probably won't get much about politics. I guess it doesn't have a political agenda either. ... I mean [giving group] is very much kind of work out what kind of charity you want to invest in and invest in it. A debate might come up like during an initial discussion session when you're trying to think about different interests and where needs, what kind of part of the NGO sector needs funding. Maybe that might lead to politics. Otherwise, I don't think, it's not really that into political discussion basically. 


\section{Discussion and Conclusions}

In this study, I have sought to understand whether giving circles-as new and emerging forms of philanthropic voluntary associations in the US and the UKincrease civic and political participation. That is, do giving circles serve as schools of democracy? From my findings, I conclude that:

- Amount of giving increases significantly with being in a giving circle in both countries, and length of engagement and number of giving circles in the US.

- Amount of volunteering increases significantly with level of engagement and length of engagement in both countries.

- Participation in addressing problems in the community due to the giving circle increases significantly with level of engagement in both countries and length of engagement in the US.

- Involvement in changing government policy due to the giving circle increases significantly with level of engagement and number of giving circles in the US.

- Participation in various civic and political activities are positively associated with being in a giving circle (significant only in the US), and these increase significantly with level and length of engagement in both countries and with number of giving groups in the UK.

Overall, then, I find:

- Participating in a giving circle seems to matter for increasing giving in both countries, and civic and political activities in the US Membership does not appear to affect the amount of volunteering.

- The level of engagement in a giving circle is associated with more volunteering, participation in addressing problems in the community, and civic and political activities in both countries, as well as more involvement in changing government policy in the US. Level of engagement does not seem to have a significant impact on giving.

- The length of engagement in a giving circle is associated with more volunteering and civic and political activities in both countries, and more giving and participation in addressing problems in the community in the US. Length of engagement does not seem to have a significant impact on involvement in changing government policy.

- The number of giving circles in which someone participates is associated with more giving and involvement in changing government policy in the US, and civic and political activities in the UK.

From the data I then conclude that, generally, giving circles do seem to serve as schools in several areas, particularly related to volunteering, participation in efforts to address problems in the community, and other civic and political activities as level and length of engagement increase. However, for some civic and political activities, particularly giving and involvement in changing government policy, giving circles have less of a schooling effect. The findings on the relationship between 
participation in these voluntary associations and civic and political participation seem to align with previous studies' findings that this relationship is generally positive for giving circles. On their basis, I also conclude that impact varies by areas and country, and the interviews indicate it varies by participant as well (Dekker, 2014).

In this study, I also provide insight into the effect of newer types of voluntary associations emerging in today's environment. As opposed to traditional, bureaucratic voluntary associations, giving circles tend to be less formal smaller groups and looser networks. The findings indicate that these structures lead to a positive impact on civic and political engagement_-perhaps more so for volunteering and participation in efforts to address problems in the community, and various civic and political activities; less so for giving or changing government policy. Thus, although giving circles represent more informal, self-organized, and decentralized forms of association emerging in a less institutionalized environment, they still seem to have a similar effect to more traditional associations. In future, researchers will need to examine more closely what particular aspects of participation in the giving circle might lead to increased civic and political participation. Through my analysis of different models of giving circles in the UK, I have found that different activities lead to different outcomes related to giving, volunteering, and learning about philanthropy and charities (Eikenberry, 2015).

Finally, what do the findings reveal related to the debate about voluntary associations as schools or pools of democracy? In general, in line with Putnam (1993, 2000) and Wollebæk and Selle (2003), the findings indicate that more active engagement (measured in this study by level and length of engagement in the giving circle and number of giving circles) can make a difference in impact on level of civic and political engagement. That is, active and sustained participation in the association seem to have greatest impact on civic and political engagement, generally supporting a schools thesis. However, the data also show that impact varies for some areas and by member-some people interviewed indicated they are already highly engaged civically and politically in various activities and the giving circle provides another opportunity for them to extend this engagement, supporting the "pools" or "selection" thesis (Armingeon, 2007; van der Meer \& van Ingen, 2009). One conclusion then is that giving circles, as well as other types of voluntary association, may serve as both schools and pools of democracy.

\section{References}

Almond, G. A., \& Verba, S. (1989). The civic culture: Political attitudes and democracy in five nations. Princeton, NJ: Princeton University Press. (Original work published 1963)

Archibald, M. E. (2007). The evolution of self-help: How a health movement became an institution. New York: Palgrave Macmillan.

Armingeon, K. (2007). Political participation and associational involvement. In J. W. van Deth, J. R. Montero, \& A. Westholm (Eds.), Citizenship and involvement in European democracies: A comparative analysis (pp. 358-383). Routledge Research in Comparative Politics: Vol. 17. Abingdon: Routledge. 
Bang, H. P., \& Sørensen, E. (1999). The everyday maker: A new challenge to democratic governance. Administrative Theory \& Praxis, 21, 325-341. https://doi.org/10.1080/10841806.199 9.11643381

Bearman, J. E. (2007a). Hosting a giving circle: The benefits and challenges of giving together. Washington, D.C.: Forum of Regional Associations of Grantmakers. Retrieved from https://www.unitedphilforum.org/system/files/resources/Hosting\%20 a\%20Giving \%20Circle \%20-\%20The\%20Benefits $\% 20$ and $\% 20$ Challenges $\% 20$ of $\% 20$ Giving\%20Together.PDF

Bearman, J. E. (2007b). More giving together: The growth and impact of giving circles and shared giving. Washington, D.C.: Forum of Regional Associations of Grantmakers. Retrieved from https://www.unitedphilforum.org/system/files/resources/More\%20Giving\%20 Together\%20-\%20The\%20Growth\%20and\%20Impact\%20of\%20Giving\%20Circles\%20 and $\% 20$ Shared $\% 20$ Giving.PDF

Bearman, J. E., Carboni, J., Eikenberry, A. M., \& Franklin, J. (2017). The landscape of giving circles/collective giving groups in the U.S., 2016. Giving Circles Research Group. Retrieved from https://scholarworks.iupui.edu/bitstream/handle/1805/14527/giving-circles2017-2.pdf

Borkman, T., Karlsson, M., Munn-Giddings, C., \& Smith, L. (2005). Self-help and mental health: Case studies of mental health self-help organizations in US, England, and Sweden. Sköndal, Sweden: Sköndalsinstitutet. Retrieved from http://urn.kb.se/ resolve?urn=urn:nbn:se:esh:diva-681

Coffey, A. J., \& Atkinson, P. A. (1996). Making sense of qualitative data: Complementary research strategies. Thousand Oaks: Sage.

Curti, M. (1973). Philanthropy. In P. P. Wiener (Ed.), Dictionary of the history of ideas: Studies of selected pivotal ideas: Law, concept of to protest movements (Vol. III, pp. 486-493). New York: Charles Scribner's Sons. (Original work published 1968)

Dekker, P. (2014). Tocqueville did not write about soccer clubs: Participation in voluntary associations and political involvement. In M. Freise \& T. Hallmann (Eds.), Modernizing democracy: Associations and associating in the 21st century (pp. 45-57). New York: Springer. https://doi. org/10.1007/978-1-4939-0485-3_4

Dekker, P., \& van den Broek, A. (1998). Civil society in comparative perspective: Involvement in voluntary associations in North America and Western Europe. Voluntas: International Journal of Voluntary and Nonprofit Organizations, 9, 11-38. https://doi.org/10.1023/A:1021450828183

de Tocqueville, A. (2000). Democracy in America (H. C. Mansfield \& D. Winthrop, Eds. and Trans., with an introduction by H. C. Mansfield \& D. Winthrop). Chicago, IL: University of Chicago Press. (Original work published 1835)

Driskell, R., \& Wise, J. (2017). Voluntary associations. In B. S. Turner, C. Kyung-Sup, C. F. Epstein, P. Kivisto, W. Outhwaite, \& J. M. Ryan (Eds.), The Wiley-Blackwell encyclopedia of social theory. New York: John Wiley \& Sons. https://doi.org/10.1002/9781118430873.est0400

Eikenberry, A. M. (2007). Giving circles: Self-help/mutual aid, community philanthropy, or both? International Journal of Self Help and Self Care, 5, 249-278. https://doi.org/10.2190/SH.5.3.d

Eikenberry, A. M. (2009). Giving circles: Philanthropy, voluntary association, and democracy. Bloomington, IN: Indiana University Press.

Eikenberry, A. M. (2015). A study of the impact of participation in UK giving circles (Unpublished report). Retrieved from https://www.academia.edu/15260901/A_Study_of_the_Impact_of_ Participation_in_UK_Giving_Circles_Full_Report

Eikenberry, A. M., \& Bearman, J. E. (2009, May). The impact of giving together: Giving circles' influence on members' philanthropic and civic behaviors, knowledge and attitudes. Retrieved from https://www.unitedphilforum.org/system/files/resources/The\%20Impact\%20of\%20 Giving\%20Together.PDF

Eikenberry, A. M., \& Breeze, B. (2015). Growing philanthropy through collaboration: The landscape of giving circles in the United Kingdom and Ireland. Voluntary Sector Review, 6, 41-59. https://doi.org/10.1332/204080515X14241771107299 
Ellison, N. (1997). Towards a new social politics: Citizenship and reflexivity in late modernity. Sociology, 31, 697-717. https://doi.org/10.1177/0038038597031004004

Fung, A. (2003). Associations and democracy: Between theories, hopes, and realities. Annual Review of Sociology, 29, 515-539. https://doi.org/10.1146/annurev.soc.29.010202.100134

Giridharadas, A. (2018). Winners take all: The elite charade of changing the world. New York: Knopf.

Gundelach, P., \& Torpe, L. (1996). Voluntary associations: New types of involvement and democracy. Paper presented at the ECPR workshop on "Social involvement, voluntary associations and democratic politics," Oslo, Norway. Retrieved from https://vbn.aau.dk/ files/95864/35031996_2.pdf

Henriksen, L. S., Smith, S. R., \& Zimmer, A. (2012). At the eve of convergence? Transformations of social service provision in Denmark, Germany, and the United States. Voluntas: International Journal of Voluntary and Nonprofit Organizations, 23, 458-501. https://doi.org/10.1007/ s11266-011-9221-5

Howard, M. M., \& Gilbert, L. (2008). A cross-national comparison of the internal effects of participation in voluntary organizations. Political Studies, 56, 12-32. https://doi. org/10.1111/j.1467-9248.2007.00715.x

Hustinx, L. (2010). I quit, therefore I am? Volunteer turnover and the politics of selfactualization. Nonprofit and Voluntary Sector Quarterly, 39, 236-255. https://doi. org $/ 10.1177 / 0899764008328183$

Hustinx, L., \& Lammertyn, F. (2003). Collective and reflexive styles of volunteering: A sociological modernization perspective. Voluntas: International Journal of Voluntary and Nonprofit Organizations, 14, 167-187. https://doi.org/10.1023/A:1023948027200

Jeong, H. O. (2013). From civic participation to political participation. Voluntas: International Journal of Voluntary and Nonprofit Organizations, 24, 1138-1158. https://doi.org/10.1007/ s11266-012-9316-7

John, R., Tan, P., \& Ito, K. (2013). Innovation in Asian philanthropy: Entrepreneurial social finance in Asia. (Working Paper No. 2). Singapore: Asia Centre for Social Entrepreneurship and Philanthropy, National University of Singapore. Retrieved from https://www.philanthropyimpact.org/sites/default/files/downloads/innovation_in_asian_philanthropy_april2013.pdf

Kahn, E. H. (2007, September 10). Demonstrating social venture partners' impact: 2007 philanthropy development report. Seattle: Social Venture Partners International. Retrieved from http:// www.socialventurepartners.org/network-office/wp-content/uploads/sites/37/2013/12/2007Summary-Report-on-Philanthropy-Development.pdf

Keeter, S., Zukin, C., Andolina, M., \& Jenkins K. (2002). The civic and political health of the nation: A generational portrait. Center for Information and Research on Civic Learning and Engagement (CIRCLE). Retrieved from http://files.eric.ed.gov/fulltext/ED498892.pdf

Lichterman, P. (2006). Social capital or group style? Rescuing Tocqueville's insights on civic engagement. Theory \& Society, 35, 529-563. https://doi.org/10.1007/s11186-006-9017-6

Lorentzen, H., \& Hustinx, L. (2007). Civic involvement and modernization. Journal of Civil Society, 3, 101-118. https://doi.org/10.1080/17448680701554282

Macduff, N. (2005). Societal changes and the rise of the episodic volunteer. In J. L. Brudney (Ed.), Emerging areas of volunteering (pp. 51-64). ARNOVA Occasional Paper Series: Vol. 1, No. 2. Indianapolis: Association for Research on Nonprofit Organizations and Voluntary Action. Retrieved from https://cdn.ymaws.com/www.arnova.org/resource/resmgr/Publications/ ARNOVA_Emerging_Areas_of_Vol.pdf

Maxwell, J. A. (1998). Designing a qualitative study. In L. Bickman \& D. J. Rog (Eds.), Handbook of applied social research methods (pp. 69-100). Thousand Oaks: Sage.

McLeod, J. M., Daily, K., Guo, Z., Eveland Jr., W. P., Bayer, J., Yang, S., \& Wang, H. (1996). Community integration, local media use and democratic processes. Communication Research, 23, 179-209. https://doi.org/10.1177/009365096023002002 
Moody, M. P. (2008). "Building a culture": The construction and evolution of venture philanthropy as a new organizational field. Nonprofit and Voluntary Sector Quarterly, 37, 324-352. https:// doi.org/10.1177/0899764007310419

Musick, M. A., \& Wilson, J. (2008). Volunteers: A social profile. Bloomington, IN: Indiana University Press.

Newton, K. (1997). Social capital and democracy. American Behavioral Scientist, 40, 575-586. https://doi.org/10.1177/0002764297040005004

Newton, K., \& Montero, J. R. (2007). Patterns of political and social participation in Europe. In R. Jowell, C. Roberts, R. Fitzgerald, \& G. Eva (Eds.), Measuring attitudes cross-nationally: Lessons from the European social survey (pp. 205-238). London: Sage.

Nickel, P. M., \& Eikenberry, A. M. (2013). Gastrophilanthropy: Utopian aspiration and aspirational consumption as political retreat. Reconstruction, 12. Retrieved from http://digitalcommons.unomaha.edu/pubadfacpub/33

Painter, M. A., \& Paxton, P. (2014). Checkbooks in the heartland: Change over time in voluntary association membership. Sociological Forum, 29, 408-428. https://doi.org/10.1111/socf.12090

Parry, G., Moyser, G., \& Day, N. (1992). Political participation and democracy in Britain. Cambridge, UK: Cambridge University Press. https://doi.org/10.1017/CBO9780511558726

Payton, R. L., \& Moody, M. P. (2008). Understanding philanthropy: Its meaning and mission. Bloomington, IN: Indiana University Press.

Pharoah, C. (2011). Private giving and philanthropy: Their place in the Big Society. People, Place \& Policy Online, 5, 65-75. https://doi.org/10.3351/ppp.0005.0002.0003

The Philanthropy Review. (2011). A call to action to encourage more people to give and people to give more: Recommendations from the Philanthropy Review, June 2011. Retrieved from https://www.philanthropy-impact.org/sites/default/files/downloads/A\%20Call\%20to\%20 Action\%20-\%20June\%202011_0.pdf

Putnam, R. D. (1993). Making democracy work: Civic traditions in modern Italy. Princeton, NJ: Princeton University Press.

Putnam, R. D. (2000). Bowling alone: The collapse and revival of American community. New York: Simon \& Schuster.

Rockefeller Philanthropy Advisors. (2009, August). Diversity funds inventory. New York: Rockefeller Philanthropy Advisors.

Rutnik, T. A., \& Bearman, J. E. (2005). Giving together: A national scan of giving circles and shared giving. Washington, D.C.: Forum of Regional Associations of Grantmakers. Retrieved from https://www.unitedphilforum.org/system/files/resources/Giving\%20Together\%20-\%20 A $\% 20$ National $\% 20$ Scan $\% 20$ of $\% 20$ Giving $\% 20$ Circles $\% 20$ and $\% 20$ Shared $\% 20$ Giving.PDF

Sargeant, A., \& Breeze, B. (2004). A blueprint for giving: The final report of the giving campaign. London: The Giving Campaign. Retrieved from https://pdfs.semanticscholar.org/4010/5 bec52876541b726742f5525bf62f20f733e.pdf

Schulz, T., \& Bailer, S. (2012). The impact of organisational attributes on political participation: Results of a multi-level survey from Switzerland. SPSR Swiss Political Science Review, 18, 1-27. https://doi.org/10.1111/j.1662-6370.2012.02052.x

Skocpol, T. (2002). The United States: From membership to advocacy. In R. D. Putnam (Ed.), Democracies in flux: The evolution of social capital in contemporary society (pp. 103-136). Oxford, UK: Oxford University Press. https://doi.org/10.1093/0195150899.003.0004

van der Meer, T. W. G., \& van Ingen, E. J. (2009). Schools of democracy? Disentangling the relationship between civic participation and political action in 17 European countries. European Journal of Political Research, 48, 281-308. https://doi.org/10.1111/j.1475-6765.2008.00836.x van der Pennen, T., \& Schreuders, H. (2014). The fourth way of active citizenship: Case studies from the Netherlands. In N. Gallent \& D. Ciaffi (Eds.), Community action and planning: Context, drivers and outcomes (pp. 135-156). Bristol, UK: Bristol University Press. https://doi. org/10.2307/j.ctt1t89cwg.15

van Deth, J. W. (Ed.). (1997). Private groups and public life: Social participation, voluntary associations and political involvement in representative democracies. London: Routledge. 
Verba, S., Schlozman, K. L., \& Brady, H. E. (1995). Voice and equality: Civic voluntarism in American politics. Cambridge, MA: Harvard University Press.

Walker, C. (2014). Give more campaign review and evaluation. London: Directory of Social Change. Warren, M. E. (2001). Democracy and association. Princeton, NJ: Princeton University Press.

Wollebæk, D. \& Selle, P. (2003). Participation and social capital formation: Norway in a comparative perspective. Scandinavian Political Studies, 26, 67-91. https://doi. org/10.1111/1467-9477.00080

Wright, K. (2001). Generosity vs. altruism: Philanthropy and charity in the United States and United Kingdom. Voluntas: International Journal of Voluntary and Nonprofit Organizations, 12, 399-416. https://doi.org/10.1023/A:1013974700175

Wuthnow, R. (1994). Sharing the journey: Support groups and America's new quest for community. New York: Free.

Wuthnow, R. (1998). Loose connections: Joining together in America's fragmented communities. Cambridge, MA: Harvard University Press.

Open Access This chapter is licensed under the terms of the Creative Commons Attribution 4.0 International License (http://creativecommons.org/licenses/by/4.0/), which permits use, sharing, adaptation, distribution and reproduction in any medium or format, as long as you give appropriate credit to the original author(s) and the source, provide a link to the Creative Commons license and indicate if changes were made.

The images or other third party material in this chapter are included in the chapter's Creative Commons license, unless indicated otherwise in a credit line to the material. If material is not included in the chapter's Creative Commons license and your intended use is not permitted by statutory regulation or exceeds the permitted use, you will need to obtain permission directly from the copyright holder.

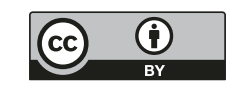

